\title{
THE INDONESIAN MILITARY IN THE MID-1990S: POLITICAL MANEUVERING OR STRUCTURAL CHANGE?
}

The Editors

During the 1990s the leadership of the Indonesian armed forces (ABRI) has undergone increasingly frequent and extensive personnel changes. Although these changes have been most noted among the higher ranking officers in the Armed Forces and Army leadership, these rotations and promotions in fact extend throughout the commissioned officer corps. Each reshuffle of senior officers stimulates a chain of further transfers, rotations, and promotions to fill vacant positions and maintain institutional integrity as well as personal networks.

In early 1992, in the wake of the Santa Cruz massacre, ${ }^{1}$ the sacking of several prominent generals stimulated a first wave of personnel changes. This was followed in mid-1992 by the replacement of all top Army leaders, the largest single overhaul of the officer corps since the mid-1980s. When they had been only just completed, these changes were followed in April and August 1993 by further waves of personnel shifts under the direction of the short-tenured Commander-in-Chief General Edi Sudradjat. The following year, 1994, saw two more major waves of personnel changes, one in January at Armed Forces headquarters and the other in August within the Army high command. The most sweeping set of transfers to date came in early 1995, involving wholesale personnel changes at the Armed Forces Headquarters and the Army central

\footnotetext{
${ }^{1}$ The background to and importance of the November 1991 massacre in the Santa Cruz cemetery in Dili, East Timor, are discussed in The Editors, "Current Data on the Indonesian Military Elite: July 1, 1989January 1, 1992," Indonesia 53 (April 1992): 137-164; hereafter cited as "Current Data" with appropriate issue number in text.
} 
and regional commands. In short, between 1992 and 1994, major personnel changes among the military elite took place twice a year; in 1995 there were five major waves of transfers, and in 1996 another four.

Observers of the Indonesian military have suggested a number of explanations for these changes and interpretations of their significance for the broader political constellation. Three of these are worth noting.

First, analysis during the early 1990s highlighted what were seen to be growing tensions between President Suharto and his "Palace Circle," on the one hand, and senior Army officers led by General L. B. (Benny) Murdani, on the other. Evaluating top military appointments during this period, the editors of the journal Indonesia paid particular attention to the tensions between military professionalism and Presidential favoritism. ("Current Data," No. 53, pp. 93, 97) The editors argued that "changes in the military leadership since early 1992 can be most profitably understood as an outcome of complex negotiations between the Palace and the military leadership represented by Edi Sudradjat." ("Current Data," No. 55, p. 181) A year later, analysis continued to highlight what were seen to be "palace-inspired countermeasures and/or supplementary rectifications" against the senior officer corps. ("Current Data," No. 56, p. 123) The upshot of this analysis was that, thanks to the craftiness of President Suharto, "the army is now deeply divided." ("Current Data," No. 58, p. 84)

The latest analysis by the editors of Indonesia continued to focus on the presumed tensions between the Palace circle and the Army elite, now, however, largely within the context of ABRI's own discourse on regenerasi. Thus large-scale transfers and promotions within the military elite were interpreted as being "directly related to the replacement of the Presidential brother-in-law, Army Chief of Staff Gen. Wismoyo Arismunandar, in February 1995 ... and the related 'regenerasi' of the Armed Forces." (“Current Data," No. 60, p. 101)

A second, more recent, line of analysis examining changes within the ABRI elite considers military-Islamic relations. Focusing on the top command positions within ABRI, Harold Crouch has argued that the appointment in 1995 of General Feisal Tanjung as Commander-in-Chief of the Armed Forces (Panglima ABRI) and R. Hartono as Army Chief of Staff reveals a move towards more cordial military-Islamic relations. ${ }^{2}$ Indeed, both Feisal and Hartono have made overtures to national as well as local Islamic leaders.

A third line of analysis concentrates on preparations for the upcoming 1997-98 parliamentary and presidential elections. According to one source, the recent transfers were intended to ensure "a similarity of political vision in the military in facing the 1997 elections and the 1998 General Session of the People's Consultative Council will be neatly in place." 3 This explanation has been encouraged by members of the military and eagerly disseminated by the Indonesian media. Contributing to this analysis, in early 1996 Harold Crouch argued that the ongoing personnel changes were not only intended to ensure that members of the military elite had a similar outlook ("pemikiran

2 “ABRI dan Islam," Tiras, February 23, 1995.

3 "Gelombang Mutasi di Tubuh ABRI," Tiras, June 29, 1995. 
yang seragam"), but also to prepare new figures to appear on the political stage following the 1997-98 elections. ${ }^{4}$

While each of these arguments contains an important element of truth about ABRI, none provides an adequate explanation for the situation at hand: the increasingly frequent and extensive personnel changes within ABRI. The appointment of two new officers to head the military is unlikely to assuage poor military-Islamic relations. Similarly, several new appointments are by no means sufficient to guarantee "a similarity of political vision" within an institution as large as the Indonesian armed forces. Finally, gossip-mongering that interprets a massive institution in terms of a few personalities and the political connections they enjoy is nothing but a substitute for analysis.

\section{Changing Size of the Officer Corps}

How, then, are we to explain the increasingly frequent transfer of senior military officers during the 1990s? The answer, I believe, does not lie in pre-election or postsuccession political posturing in Jakarta, but rather in Magelang, Central Java, home of the Akademi Militer Nasional (National Military Academy, AMN), some three decades ago.

The AMN was established in 1957 as part of then-ABRI Commander-in-Chief General Nasution's ongoing effort to turn a regionally-based guerrilla army into a professional as well as national military. ${ }^{5}$ Inducted in 1957, the first AMN class totaling fifty-nine officers graduated three years later, in 1960. The following three AMN Classes (1961-63) averaged 125 graduates each. During the next several years, however, the intake of cadets and size of graduating AMN classes varied widely. The total doubled in each of the next years, with Class 51964 graduating 280 officers and Class 61965 graduating 433 officers. Although the number of graduates fell to an average of two hundred officers for the next two years, class size again peaked after that, with Class 91968 graduating 465 officers. Because of the institutional shift introduced in 1965 from a three- to a four-year educational program and the change of name from AMN to Akademi Militer (Akmil), no class graduated in 1969. And although Class size continued to fluctuate, between 1970 and 1975 Akmil graduated an average of four hundred officers per year. (See Table 1.)

\footnotetext{
4 "Crouch: ABRI Rapatkan Barisan," Merdeka, February 24, 1996. The article reports that "ABRI leaders are now preparing champions to be brought forward when the time is right" ("pimpinan ABRI saat ini sedang mempersiapkan jago-jagonya untuk ditampilkan pada saatnya nanti").

5 Ruth McVey, "The Post-Revolutionary Transformation of the Indonesian Army," Indonesia 11 (April 1971): 131-176, and Indonesia 13 (April 1972): 147-182.
} 
94 The Editors

Table 1

Cadets Graduated from the National Military Academy

\begin{tabular}{ccc}
\hline $\begin{array}{c}\text { Class } \\
\text { Number }\end{array}$ & Year & $\begin{array}{c}\text { AMN and AKMIL } \\
\text { Graduates }\end{array}$ \\
\hline 1 & 1960 & 59 \\
2 & 1961 & 151 \\
3 & 1962 & 112 \\
4 & 1963 & 113 \\
5 & 1964 & 280 \\
6 & 1965 & 433 \\
7 & 1966 & 243 \\
8 & 1967 & 203 \\
9 & 1968 & 465 \\
& 1969 & no class \\
10 & 1970 & 437 \\
11 & 1971 & 329 \\
12 & 1972 & 389 \\
13 & 1973 & 436 \\
14 & 1974 & 434 \\
15 & 1975 & 304 \\
16 & 1976 & 85 \\
17 & 1977 & 79 \\
18 & 1978 & 93 \\
& 1979 & no class \\
19 & 1980 & 102 \\
20 & 1981 & 146 \\
21 & 1982 & 85 \\
22 & 1983 & no class \\
& 1984 & 244 \\
\hline
\end{tabular}

Source: Madjalah Akabri (various); mimeographed class list circulating in Jakarta, source unknown. It should be noted that the Class numbering system used here differs from that in our previous listings.

There is no official explanation for this wide variation in the size of AMN/Akmil graduating classes during the 1960 s and early 1970s. Several possibilities are available, however. First, when the AMN opened in 1957, it was not the only military academy in Indonesia. Even after the AMN opened, the Academy for Military Technology in Bandung (Akmil Jurtek), a training ground for army engineers and technical specialists, continued to operate. Between 1964 and 1966, however, technical programs gradually were moved from Akmil Jurtek in Bandung to the AMN in Magelang, thus adding an additional 120 cadets to the AMN class total.

Curriculum development at the AMN was not limited to institutional consolidation. When the AMN first opened, educational specialization was limited to four expressly military courses: Infantry, Cavalry, Artillery, and Anti-aircraft. In 1964, along with the addition of the first course from the Akmil Jurtek Bandung, the AMN 
also added a series of further specializations-Military Police, Transport, Quartermaster, Health, Adjutant General, Finance, and Law. But if this expansion of the military curriculum and total number of cadets was initially part of General Nasution's effort to professionalize the military, it also, undoubtedly, squared well with the army's ongoing power-struggle with Sukarno and the PKI. Specialization and professional skills would be necessary for the military's expansion into the economy and the state. It was this expansion of the curriculum that first swelled the AMN class size from an average of 120 officers to 280 officers graduating in 1964.

Less easily explained is the further doubling in the number of cadets inducted into the AMN in 1962 and graduated as officers in Class 6 1965. The available data reveals that it was not an increase in the number of courses or specializations offered that swelled the number of officers (courses in fact were reduced by two), but rather a near threefold increase in the number of Infantry cadets inducted. The most plausible (although wholly unsubstantiated) explanation is that this was a response to international political tensions, specifically the 1962 Mandala campaign to seize Dutchheld Irian Barat and the 1963 Konfrontasi with Malaysia, and the perceived need for officers to command combat troops. Interesting as it might be to know the reasons for this increase in Infantry cadets, for our purposes it is sufficient to note that Class 61965 was thus substantially larger than all previous AMN classes, a point to which I will return shortly.

The drop in the size of AMN Class 71966 and Class 81967 resulted from a combination of the above two factors. While the total number of graduating Infantry cadets dropped roughly 25 percent, these years also saw the suspension of a number of service specializations, including Transport, Quartermaster, Health, and so forth. These reductions were temporary, however, and Class 91968 ballooned to 466 graduates, the largest ever. Here, too, the increase is seen in the number of Infantry cadets, the total rising to 331 or fully three-quarters of the entire class. Again, it is not clear if this increase was related to external security concerns, as I suggested in the case of Class 61965 , or internal military politics involving the institutional shift from the AMN to Akmil. 6

In any case, this tremendous increase and the subsequent fluctuation in the size of the army officer corps graduating from the AMN and Akmil in the 1960s and early 1970 s raises a series of related problems. Given that the number of upper-level positions within the military has remained roughly constant, this variation in the size of the officer corps could have a direct and lasting impact on the promotional prospects of these officers. On the one hand, the swollen class size means that a smaller percentage of officers from a given AMN class could be promoted to senior ranks and given correspondingly strategic and/or lucrative postings. On the other hand, the relative "success" of a single, large AMN class might hold back the promotion of subsequent classes. In either case, the resulting deterioration of promotional prospects would likely lead to discontent among the officer corps.

Over the past several years, members of the Indonesian military elite have intimated that just such a promotional log-jam is taking place within both the Army

${ }^{6}$ These figures are only for Army cadets (Angkatan Darat), not for all four service branches at the newly reconstituted Akmil. 
and the Armed Forces high command. In March, 1996, Forum Keadilan titled a special feature "When there is a Promotional Log-jam at the Top." The feature examined the institutional dilemma "when, for the first time ever, two Lieutenant Generals are entitled to be promoted to the same position" and went on to note that two other active Lieutenant Generals were still awaiting assignment because no positions were vacant. ${ }^{7}$ Major General Theo Syafei, a member of the ABRI Fraction of Parliament (F-ABRI DPR RI) labeled the problem "General Inflation," attributing it the policy of assigning rank on the basis of an officer's position within the Armed Forces. Syafei's comments initiated a highly revealing debate over the current system and procedures for transfers and promotions with ABRI. Tati Darsoyo, another member of the ABRI Fraction of Parliament, questioned the root of the dilemma: "Is this [issue of assignments] wrong and problematic because we assign position and role in accordance with rank or because of some other reason?" Similarly, the usually staid Minister of Security, General Edi Sudradjat, asked flatly "Are rotations taking place too quickly?" In answer to his own question, Edi noted that the military as an institution would settle the matter, a clear reference to maintaining a hierarchy that honored military professionalism over personal or Palace preference. 8

Although public debate was limited to the assignment of senior officers, the problem is not. Indeed, as I will argue, the underlying problem may not be "rank inflation," but rather the changing size of the officer corps and the structural pressures that this is placing on the Armed Forces as an institution.

If aware of the dilemma posed by a promotional log-jam, the Indonesia military elite could respond in several ways. One response would be to accelerate the transfer and rotation of officers while reducing their individual tenure in a given position, thus providing as many officers as possible an opportunity to hold the much-coveted command positions. A second response would be to exploit the opportunity presented by excess commissioned officers through even greater job specialization. Third, the military elite could seek non-military assignments for active officers so as to relieve some of the competition for postings; this raises the sensitive issue of "dinaskarya" - the policy of assigning military officers to positions in the civil bureaucracy. Finally, army leadership might respond by seeking early retirement for officers deemed to be expendable or of less than exceptional capacity. While I believe that ABRI has in fact used each of these strategies to differing degrees, the remainder of this essay will explore the first of these strategies.

\section{Command Tenure}

We can begin our evaluation of the above logic by considering the length of tenure and graduating class of Army commanders at various levels. Institutional rationality calls for militaries to space the rotation of officers as evenly as possible, normally at two year intervals. There are two reasons for this: first, a sufficiently long tenure is necessary to ensure regional stability; second, regular rotations help to ensure that

\footnotetext{
7 "Bila Gerbang Mutasi Macet di Atas," Forum Keadilan, March 25, 1996, pp. 12-14. The article, of course, overstates its case: this was a common occurrence during the 1950 s and early 1960 s.

8 "Pangab Mengenai Tiga Letjen tak Punya Jabatan," Kompas, March 6, 1996.
} 
officers' expectations are fulfilled and thus prevent rash action-what members of the Indonesian military elite nervously refer to as "political adventurism."

In this light, we begin by considering the changing length of tenure of the ten Regional Military Commanders (Panglima Kodam, Pangdam). The data in Table 2 show that over the past decade the average tenure of the ten Pangdam has been cut in half, from a full two and a half years during the mid-1980s to a mere sixteen months for the last full posting, in the mid-1990s. In other words, the rotation of officers serving as Pangdam has accelerated dramatically over the past decade.

\section{Table 2}

Tenure of Regional Military Commanders (in months)

\begin{tabular}{lcrrrrc}
\hline \multicolumn{6}{c}{ Previous commanders (in reverse order from present, March 1, 1997)* } \\
\hline & 5 & 4 & 3 & 2 & 1 & Current \\
\hline Kodam I & 14 & 22 & 34 & 16 & 13 & $17+$ \\
Kodam II & 41 & 12 & 12 & 10 & 14 & $6+$ \\
Kodam III & 25 & 37 & 31 & 26 & 24 & $23+$ \\
Kodam IV & 18 & 24 & 9 & 22 & 9 & $14+$ \\
Kodam V & 24 & 27 & 33 & 34 & 16 & $23+$ \\
Kodam VI & 34 & 39 & 3 & 11 & 20 & $23+$ \\
Kodam VII & 36 & 21 & 5 & 21 & 17 & $6+$ \\
Kodam VIII & 42 & 10 & 13 & 12 & 12 & $6+$ \\
Kodam IX & 41 & 7 & 7 & 10 & 19 & $17+$ \\
Kodam Jaya & 31 & 29 & 32 & 20 & 16 & $11+$ \\
\hline average & 30.6 & 22.8 & 17.9 & 18.2 & 16.0 & $14.6+$ \\
\hline
\end{tabular}

* The vertical row to the right of the chart lists tenure, in months, for commanders who currently direct each Kodam. Vertical row " 1 " records tenure, in months, for each commander who held the office previous to the current commander; vertical row " 2 " records tenure for the commander who held the post prior to " 1 ," and so on.

Political observers, the mass media, and scholars commonly provide analysis of personnel changes, particularly in the case of brief command tenures and "snap" personnel changes. The reasons for such cases of "shortened" command tenure commonly include unsatisfactory performance, the need to hold someone accountable for military misconduct (in incidents such as the 1991 Santa Cruz massacre), mandatory retirement, and so forth. When evaluated case by case, these explanations clearly bear weight; but case-by-case considerations cannot explain the overall shift in the length of tenure of Pangdam illustrated in Table 2. The problem thus remains: how to explain the structural shift in the tenure of Pangdam.

The argument developed in the preceding section suggests that the reduced tenure and more frequent personnel changes are part of a larger response to the changing size of the Army officer corps. This in fact becomes all the more evident when we consider the "fate" of particular AMN classes. In this vein, a previous update noted: "the unusually large Class 6 (1965) officers held back Class 7 and possibly Class 8 from reaching command positions in Korem in the late 1980s and early 1990s. Now dominant in the army central and regional commands, Class 6 officers again threaten 
98 The Editors

to hold back Class 7,8, and 9 from reaching staff and command positions in the army central and regional commands." ("Current Data," No. 58, p. 86) This much is clearly correct. More remarkable still is that a number of Pangdam-ships have not simply been monopolized by members of the class of 1965 , but that this has involved "job sharing" among AMN classmates. ${ }^{9}$ To illustrate this, Table 3 lists the AMN graduating class of each officer who held each Pangdam-ship from 1985 until the present.

Table 3

Graduating Classes of Regional Military Commanders, listed by class number**

\begin{tabular}{|c|c|c|c|c|c|c|c|c|c|}
\hline & 1985 & $\rightarrow$ & $\rightarrow$ & $\rightarrow$ & $\rightarrow$ & $\rightarrow$ Present & & & \\
\hline Kodam I & 1 & $?$ & * & 3 & 2 & 3 & 4 & 7 & 7 \\
\hline Kodam II & * & 2 & 3 & 5 & 6 & 6 & 6 & 13 & \\
\hline Kodam III & 2 & 3 & 3 & 6 & 7 & & & & \\
\hline Kodam IV & 1 & 2 & 4 & 4 & 5 & 6 & 7 & 10 & \\
\hline Kodam V & $*$ & 1 & 3 & 6 & 6 & & & & \\
\hline Kodam VI & 2 & 2 & 2 & 3 & 6 & 6 & & & \\
\hline Kodam VII & 1 & 2 & 3 & 6 & 6 & 6 & 9 & & \\
\hline Kodam VIII & 1 & 2 & 4 & 2 & 5 & 6 & 7 & 8 & 10 \\
\hline Kodam IX & * & 2 & 4 & 3 & 3 & 6 & 8 & 7 & \\
\hline Kodam Jaya & 2 & 3 & 2 & 8 & 9 & 9 & & & \\
\hline
\end{tabular}

Note: * denotes an officer educated prior to the creation of the AMN (e.g. at Aktekad Bandung). ** Officers from Class 1 graduated in 1960, officers from Class 2 graduated in 1961, officers from Class 3 in 1962, and so forth.

Thus the position of Pangdam II Sriwijaya (south Sumatra) was held by three members of the Class 61965 , each serving for roughly one year. ${ }^{10}$ Similarly, Kodam VII Wirabuana (Sulawesi) had three consecutive Pangdam from Class $61965 .{ }^{11}$ Kodam V Brawijaya (East Java) and Kodam VI Tanjungpura (Kalimantan) have each had two consecutive Pangdam from Class $61965 .^{12}$ Finally, four of the remaining five Kodam previously had one member of Class 61965 serve as Pangdam.

These figures organized by AMN class can be simplified to show the total number of officers from each AMN class to serve as Pangdam. This provides one measure of

\footnotetext{
9 This argument throws further light on the analysis made in "Current Data," Indonesia 55 (April 1993): 180, which attributes the long hold of Class 61965 on Pangdam-ships to class solidarity and the reported policy of allowing outgoing officers to recommend their replacement. While this may in fact be the case, it will likely carry less weight in consideration of officers to be posted as Pangdam than it will for middleranking officers (e.g. Dandim).

${ }^{10}$ These officers were: Syamsir Siregar (1993-94), Yunus Yosfiah (1994-95) and R. Karyono (1995-96).

11 Sofian Effendi (1993-94), Tamlicha Ali (1994-95) and Sulatin (1995 to present).

12 For Kodam V Brawijaya: Haris Sudarno (1993-95) and Imam Utomo (1995 to present). For Kodam VI Tanjungpura: Yacob Dasto (1994-95) and Namuri Anoem (1995 to present)
} 
the relative "success" of each AMN class. Taking into account those officers who served as Pangdam in more than one location, ${ }^{13}$ the totals are:

Table 4

Pangdam by AMN Class

\begin{tabular}{rc}
\hline Class & Total Pangdam \\
\hline $1(1960)$ & 5 \\
$2(1961)$ & 9 \\
$3(1962)$ & 9 \\
$4(1963)$ & 4 \\
$5(1964)$ & 3 \\
$6(1965)$ & 14 \\
$7(1966)$ & 6 \\
$8(1967)$ & 3 \\
$9(1968)$ & 3 \\
$10(1970)$ & 2 \\
$11(1971)$ & - \\
$12(1972)$ & - \\
$13(1973)$ & 1 \\
$14(1974)$ & - \\
& \\
\hline
\end{tabular}

Clearly, then, the military leadership has responded to variations in the size of the officers corps at the senior level not only by reducing the length of tenure of Regional Military Commanders, but by instituting a form of "job sharing" among members of a given AMN class to ensure that the career ambitions of senior officers are satisfied. The result of this, however, is to hold back the promotion of members of Classes 7, 8 and 9 to the much-coveted Pangdam commands.

By all indications a similar acceleration in the transfer and rotation of officers has taken place elsewhere in the army. At the Sub-Regional Command (Korem) level the aggregate data from the thirty-eight Korem show a less dramatic but nonetheless significant reduction in command tenure. Whereas during the 1980s a Korem commander enjoyed a tenure of twenty months, this has fallen over the past four to five years, with the last full posting averaging a mere twelve months.

Table 5

Tenure of Sub-Regional Military Commanders (Danrem)

(in months)

\begin{tabular}{cccccccc}
\hline & \multicolumn{6}{c}{ Officer holders (in reverse order from present) } \\
\hline & 5 & 4 & 3 & 2 & 1 & current commander \\
\hline average & 19.6 & 20.8 & 19.9 & 17.8 & 12.4 & $11.1+$ \\
\hline
\end{tabular}

* See note, Table 2 above.

${ }^{13}$ A decade ago it was not uncommon for a Major General to serve as Pangdam in more than one location, something that is now unheard of. 
100 The Editors

This acceleration of Danrem transfers takes on added importance given the emphasis placed on this position following the 1985 army reorganization. At the time of the 1985 streamlining of regional commands, Commander-in-Chief General Benny Murdani announced that these "new-style Korem" would be the "meritocratic breeding-ground of future military leaders of the nation."14 Full analysis of the importance of Korem command in determining future military leadership would require evaluating the career trajectories of the approximately three hundred officers who have served as Danrem since the 1985 reforms, a task whose accomplishment is precluded by current time constraints. ${ }^{15}$ The evidence cited above regarding reduced tenure of Korem commanders over the past several years, however, strongly suggests that such a strictly meritocratic policy is not being implemented. Rather, a case can be made that the problems posed by a swollen officer corps have led to shortened command tenure, thus offering less opportunity for Danrem to fully master the particular challenges of their commands and, consequently, reducing the base of evidence available to those who might try to evaluate meritocratically an officer's performance.

Analysis of command tenure is perhaps most important at the middle ranks, particularly for District Military Commands (Kodim), the commander of which holds the rank of Lieutenant Colonel. Corresponding roughly to the Kabupaten (Regency) administration, the three hundred or so Kodim are the nexus of social control and national security. Unfortunately, relatively scarce reporting in the print media makes analysis of command tenure most difficult at the Kodim level. And while the available data do suggest that the tenure of Kodim commanders has decreased marginally over the past decade, statistical analysis is not possible. Nonetheless, several observations can be made.

First, tenure of Kodim commanders appears to be shortest in urban centers (one to two years), longest in rural areas (two to four years). Assignment as Kodim commander in the urban centers of Jakarta, Semarang, Surabaya, and Medan is generally a sign of a rising career. After one and a half to two years of service, such an officer can expect to be promoted to serve as a deputy assistant to the chief of staff of a Kodam or as Chief of Staff to a Korem commander in the same region. Assignment as Kodim commander in a rural area, however, is likely as not to last for two to four years and signal career stagnation. Following such a long posting in a rural backwater, the best that could be hoped for would be a civilian posting as Bupati (Regent) or Walikota (mayor).

Second, in contrast to the prevailing patterns that determine assignments for Kodam and Korem commanders, it is not uncommon for an officer to be posted as Kodim commander on more than one occasion, in different regions. For some officers, assignment as Kodim commander in a second-tier city may be a stepping-stone to a subsequent posting as Kodim commander in a larger urban center. Thus the Kodim

14 Quoted in "Current Data," Indonesia 48 (October 1989): 67-68.

15 Alternatively, we might consider that of the forty-three Kodam commanders installed since January, 1990 , fully 80 percent (34) have previous experience as Korem commanders, and nine of these were involved in Korem encompassed by the Kodam they were ultimately promoted to command. These figures on the career paths of Kodam commanders diverge sharply from those found by Anderson in the late 1980s. See Ben Anderson, "Current Data," Indonesia 48 (October 1989): 67. 
commander of Padang may be transferred to Batam, that of Banyumas to Semarang, and so forth. While such a transfer will entail greater responsibility and new opportunities to accumulate personal wealth, such officers rarely rise above the rank of colonel. They are, for all intents and purposes, local specialists. For officers in rural areas, assignment as Kodim commander in more than one location clearly signals career stagnation.

In sum, during the 1990s the Indonesian army has experienced increasingly rapid transfers of middle-ranking and senior officers. This has included shortened tenure for Kodam and Korem commanders as well as "job sharing" among classmates at the higher ranks. These changes in the army officer corps cannot not be explained by arguments that focus on the legacy of Benny Murdani, by appeals to military-Islamic relations, or by the need to "prepare" for the 1997-98 elections. They are, rather, first and foremost a function of structural features of the changing size of the army officer corps. The increase in the number of cadets graduating from the AMN and Akmil during the 1960s and early 1970s has, some thirty years later, placed new pressure on the army to satisfy career ambitions. One response available to the military elite has been to decrease command tenures and accelerate rotations of officers.

\section{The Promotional Log-Jam Exacerbated?}

What, then, is the relationship between the promotional log-jam and the 1997-98 parliamentary and Presidential "elections"?

As early as November 1995 military leaders announced that the ongoing waves of personnel rotations were in preparation for the May 1997 elections, a full year and a half away. ${ }^{16}$ Several months later, following an additional wave of personnel changes, members of the military elite made increasingly frequent statements that further transfers would not take place until after the 1997 Parliamentary elections. In February 1996, ABRI Commander-in-Chief General Feisal Tanjung announced that "in principle" there would be no further transfers after the 1997 elections, but that if any did take place, they would be "few in number and most likely not involve field commanders but rather staff positions." 17 With reference to the politically sensitive Kodam commanders, ABRI Commander-in-Chief General Feisal Tanjung commented that "the corps of Kodam commanders remains solid," 18 noting specifically that "the Commander of Kodam Jaya (Jakarta), Major General Wiranto, will continue to hold his position until the 1997 election." 19 If implemented this pre-election policy would effectively serve to exacerbate the existing promotional log-jam within the army elite, thus holding back the careers of hundreds of middle-ranking officers. It was on the basis of such official statements that a number of observers argued that the most recent waves of transfers were intended to ensure "a similarity of political vision in the

\footnotetext{
16 "Peluang Lulusan AMN Kian Mengecil: Mutasi di Tubuh ABRI Berkaitan dengan Pemilu," Merdeka, November 20, 1995.

17 "Pangab: Prinsipnya, Sampai Pemilu tak Ada Lagi Mutasi," Kompas, February 17, 1996.

18 "Pangab: Barisan Pangdam Masih Solid," Merdeka, February 17, 1996.

19 "Hingga Pemilu tidak ada Pergantian Pangdam," Media Indonesia, February 17, 1996.
} 
102 The Editors

military in facing the 1997 elections."20 Yet official statements proved to be misleading at best.

A mere one month later, in mid-March, 1996, an additional wave of personnel rotations took place in the Armed Forces and army high commands. These rotations included the strategic appointments of Lieutenant General Wiranto as Kostrad commander, his replacement as Kodam Jaya (Jakarta) commander by Major General Sutiyoso, and the appointment of the rising star Major General Yudhoyono as Chief-ofStaff Kodam Jaya. ${ }^{21}$

These personnel transfers were followed by a curious series of statements by senior military brass. In May, 1996, Army Chief-of-Staff General R. Hartono announced that "in addition to organizational requirements, the change of Kodam commanders is related to the upcoming 1997 election." He noted, furthermore, that while he could only make suggestions, the final decision lay with ABRI Commander-in-Chief Feisal Tanjung. ${ }^{22}$ Given that Feisal had repeatedly stated that there would be no further rotations prior to the May 1997 elections, these comments appear more as a challenge to than acknowledgment of the Pangab's authority. In June, ABRI Chief of Staff Lieutenant General Soeyono added a further note, warning that if members of AMN Class 101970 were not appointed to senior positions by 1997 that "our regeneration will be late and [the officers] will be slow to mature." 23 Again, in obvious contradiction to the numerous statements made by ABRI Chief-of-Staff Feisal Tanjung, Soeyono noted that the tenure of current Kodam commanders could not be extended simply because of the 1997 election.

Indeed, despite the flurry of official statements about pre-election promotional policy, yet another wave of personnel changes was announced in August. This, the fourth major personnel reshuffling of the year, included the replacement of three Kodam commanders: Brig. Gen. Yudhoyono was installed as commander of Kodam II Sriwijaya (south Sumatra), Major General Agum Gunelar as commander of Kodam VII Wirabuana (Sulawesi), and Maj. Gen. Johnny Lumintang as commander of Kodam VIII Trikora (Irian Jaya). ${ }^{24}$ These moves were followed in September by a fifth reshuffling, this involving another one hundred senior officers. ${ }^{25}$ Despite official statements to the contrary, personnel changes were not only continuing, but in fact intensifying.

How then are we to interpret Feisal Tanjung's repeated claims that transfers would be postponed until after the election? It can scarcely be doubted that ABRI is preparing for the 1997 elections. Senior military officials make nearly daily statements about the necessity of "safeguarding" the election. They offer warnings that ABRI will not tolerate disruption of the electoral process. And the military daily Angkatan Bersenjata

\footnotetext{
${ }^{20}$ See, for example, the interview with Harold Crouch, "Crouch: ABRI Rapatkan Barisan," Merdeka, February 24, 1996, and "Dr. A. Yahya Muhaimin: Pergantian Pimpinan ABRI Mengantisipasi Pemilu 1997," Kompas, March 11, 1996.

21 See, for example, "Empat Mutasi di tubuh ABRI dalam 50 Hari," Republika, March 18, 1996.

22 "Pergantian Pejabat TNI AD Berkait dengan Pemilu," Kompas, May 27, 1996.

23 "Perwira angkatan 70 harus berperan sesudah Pemilu nanti," Angkatan Bersenjata, June 16, 1996.

24 "Pergantian di ABRI: Dari Angkatan '65 ke Angkatan '65," Republika, August 12, 1996.

${ }^{25}$ See, "Jabatan Assospol Kassospol serta Danpussenif diserahterimakan," Angkatan Bersenjata, September 23, 1996, and "70 Pati ABRI alih jabatan," Angkatan Bersenjata, September 24, 1996.
} 
commonly reports on the training of special troops (complete with riot gear) to prevent unrest during the election period. But these moves do not adequately explain the ongoing personnel changes, nor the apparent inconsistencies between official statements denying that further personnel changes would take place and the ongoing appointment of new Kodam commanders.

One alternative view, building on a previous analysis offered by "Current Data on the Indonesian Military," is that the March and August waves of personnel changes represent Palace initiatives pushed through against the will of senior military leaders. In this regard, the promotion of Major General Wiranto to the strategic post of Kostrad commander and his replacement by Major General Sutiyoso would appear to strengthen Presidential security. The same, too, can be said of the appointment of a host of Akabri Class 141974 graduates to strategic commands throughout the greater Jakarta area, for class leader Kopassus Commander Major General Prabowo is a Presidential son-in-law. But while such an analysis can account for the appointment of a few individuals, it cannot explain the necessity of increasingly rapid personnel changes.

Another possible explanation, proposed here, is that despite an official desire to maintain the current command line-up, continued personnel rotations are necessary to prevent an increasingly serious promotional log-jam. This is true not only at the pinnacle of the officer corps, but also among the middle-ranking officers who form the heart and soul of the national security system. This is not to deny that the President may benefit from the current personnel shifts. In other words, the necessity of maintaining institutional rationality through the continued transfer and promotion of army officers may be forcing the hand of the military elite in a way that in fact coincides with President Suharto's interests. The rapid rotation of Kodam and Korem commanders limits the possibility of an officer developing a regional "interest" or personal influence over troops. And the ongoing transfers have allowed the President to appoint a core group of officers in and around the capital who not only share similar interests, but whose interests largely concur with those of the President.

If the above analysis is correct, it remains to consider where the Indonesian military stands vis-à-vis promotional changes. In other words, how serious is the threat posed by the changing size of the officer corps? It appears that thanks to the ongoing personnel changes, the Indonesian army may already have survived the most obvious and direct threat posed by promotional dissatisfaction among the middle and senior ranking officer corps. The last remnants of AMN Class 61965 are on the verge of mandatory retirement at age fifty-five. Although AMN Classes 7,8 and 9 have seen a smaller percentage of officers reach top command and staff positions, there is no possibility of career frustration leading these officers to mount any sort of collective action against either military leadership or the President.

\section{Divisions within the Officer Corps}

This, however, does not mean that the changing size of the army officer corps poses no problems for the Indonesian military. It does so in several less apparent but equally important ways, three of which are worth briefly noting.

First, career prospects for Akmil graduates of the early 1970s are relatively poor, and dissatisfaction is likely to arise among those officers who are not promoted beyond 
104 The Editors

the rank of Lieutenant Colonel. One possibility is that career stagnation will make officers reluctant to use heavy-handed measures against civilian protest. With little or no hope of further promotion, there is little reason for these officers to take a tough stand on social unrest. This is particularly true when one considers that the best that these officers can hope for is to be appointed as Bupati (Regent) or Walikota (Mayor) after retirement, ${ }^{26}$ and that such an appointment may well be in a region where one has had active service experience. There is circumstantial evidence that Kodim commanders in second-tier cities have "softened" their approach toward social and political movements over the past several years.

A second division within the army is emerging between active and retired officers. Facing mandatory retirement at the relatively young age of fifty-five, army officers could look forward to civilian postings-dinaskarya-as Bupati, Walikota, or a local legislative member (DPRD). These appointments not only provided the military with a second layer of social control, but also provided employment for retired officers. Indeed, the need to provide meaningful employment (and financial remuneration) to retired officers has been as influential a factor as "militarization" of the state in prompting the appointment of military officers to civilian positions. Although the benefits vary by region, these postings have been so attractive as to lead to sharp "electoral" competition. ${ }^{27}$ Although the percentage of Bupati from the military fell from 50 percent to 41 percent during Rudini's tenure as Interior Minister, the figure has remained largely unchanged, in 1996 standing at 44 percent. ${ }^{28}$ The retirement of the relatively large AMN and Akmil classes that graduated in the late 1960s and early 1970s will place increased pressure on the state and bureaucracy to accommodate the personal and financial aspirations of even more retired military officers. Despite these needs, senior retired officers recently have called for ABRI to retreat from some (though certainly not all) of its social and political activities. It is unclear, however, if these calls simply represent. dissatisfaction with President Suharto or are part of a genuine desire to allow greater space for civilian rule. In any case, military top brass are quick to acknowledge that retired officers may have an important influence on social and political developments. ${ }^{29}$

Third, the stabilization in Akmil class size during the first half of the 1970s was not permanent. In 1972 Akmil "admits" fell precipitously to under one hundred cadets, with a mere eighty-five officers graduating four years later in Akmil Class 161976. With slight variation, this admission and graduation level was maintained until 1982. It was not until 1984 that Akmil class size again increased, rising to 250 cadets, a level that has been maintained ever since. This total appears to represent the actual needs of the army. What is clear, however, is that this reduction, like the dramatic increase a decade earlier, must have important ramifications for the armed forces. These smaller

\footnotetext{
${ }^{26}$ As they are situated outside of the normal military chain of command, these postings require political savvy and a proven ability to get along with the civilian bureacracy.

27 An article in the armed forces daily Angkatan Bersenjata noted that in Karawang, one of the fastest growing industrial regions and thus one ripe with financial opportunity, there was great interest in becoming Bupati. See, "Mendorong Banyak Peminat Jadi Bupati," Angkatan Bersenjata, October 11, 1995.

${ }^{28}$ See, The Editors, "Current Data on the Indonesian Military Elite," Indonesia 53 (April 1992): 97, and "Tak ada jatah ABRI atau sipil dalam jabatan Kepala Daerah," Angkatan Bersenjata, May 29, 1996.

29 "Purnawirawan warnai kondisi sosial politik," Angkatan Bersenjata, September 27, 1996.
} 
Akmil classes will see a higher percentage of their members become senior officers and be appointed to strategic command and staff positions. The structural needs of the army for a set number of commissioned officers at any one time also mean that those classes immediately preceding this reduction-Classes 141974 and 15 1975-will also enjoy improved promotional prospects.

But while individual career prospects will improve, the general situation poses further structural problems and is bound to lead to important consequences. These smaller Akmil classes will in fact not be sufficient to fill all of the command positions within the army. There are, to take just one example, currently some two hundred and eighty Kodim units in Indonesia, each under the command of a commissioned officer. It will thus take more than three full Akmil classes from the late 1970s to staff these positions alone. ${ }^{30}$

Fourth and finally, in the short-run the greatest beneficiary of these fluctuations in the size of the army officer corps will be Class 14 1974. Led by Presidential son-in-law Major General Prabowo, Commander of the elite Kopassus special forces, this class is politically well-placed. Indeed, its monopoly on staff and command postings in and around Jakarta suggests that the July, 1996 attack on PDI (Indonesia Democratic Party) headquarters was carried out by these officers. Yet the excellent career prospects of this and subsequent classes also suggest that these classes will seek to maintain the status quo, for officers who foresee better career prospects for themselves would have more to lose from political adventurism.

\section{Conclusion}

This essay has argued that the increasingly frequent personnel changes among the Indonesian military elite during the 1990 s are best understood as a function of the changing size of the army officer corps. But while the rapidity of personnel rotations and promotions is a clear response to the swollen size of the officer corps, the reduced size of Akmil Classes beginning in 1976 will lead to a corresponding slow-down in personnel changes in the very near future, thus producing greater stability within the military.

In the final analysis, such intra-military dynamics will largely determine what room for maneuver is available to civilian groups seeking political change in Indonesia. The emergence of a truly independent political party in New Order Indonesia will not be possible without tacit approval from at least a fragment of the Armed Forces. Indeed, the possibility of a civilian politician such as Megawati making a serious run at the Presidency will only be possible if a fraction of the military eliteeither active or retired-provides support and a degree of protection.

30 One means of overcoming this shortage of commissioned officers would be to allow the appointment of NCOs to higher levels of command. 
